\title{
Change of the functional purpose of the object through urbanistic analysis
}

\author{
Liliia Talipova ${ }^{1 *}$, Egor Kosyakov ${ }^{1}$, Marina Romanovich ${ }^{1}$ and Mikhail Lunyakov ${ }^{2}$ \\ ${ }^{1}$ Peter the Great St. Petersburg Polytechnic University, 29 Politechnicheskaya St., St. Petersburg, \\ 195251, Russia \\ ${ }^{2}$ Moscow State University of Civil Engineering, Yaroslavskoe shosse, 26, Moscow, 129337, Russia
}

\begin{abstract}
This article is devoted to changing the functional purpose of the object in an emergency condition and included in the "gray belt" of Saint Petersburg. The analysis of the physical and social environment of the study area was carried out. By results of the study, a SWOT analysis was compiled, and the option of the functional change for co-living was considered. The purpose of co-living is to create a home environment that inspires and empowers its residents to be active creators and participants in the world around them. The necessary investments and the payback period of this project were calculated, the business model was developed.
\end{abstract}

\section{Introduction}

At the beginning of the 20th century, in 1905 civil engineer V. Korvin-Krukovsky constructed the building of the Kudryavtsev baths on Kurskaya st., 11. On March 17, 1906, in this four-story stone wing with a penthouse, Philip Kuzmich Kudryavtsev opened the commercial baths of three categories. In 1985 the building was abandoned. At the moment the object does not function due to critical condition. It is a historic building that forms the street front of the buildings of Kurskaya and Voronezhskaya streets and located on the territory of the "Gray Belt" of St. Petersburg.

Gray Belt "is a territory located between the city center and the dormitory areas. Early given territory was used for industrial enterprises and the accompanying housing for workers. At the moment many objects are abandoned and in a critical condition [1-3].

At the moment, the city government has banned the demolition of objects, because they are included into the list of objects of cultural heritage. The main task was to preserve and transform them, including change of functional purpose. Within reconstruction, there is a number of restrictions on which the object can not be demolished and the external appearance can not be changed. Only the demolition of the attached building - the boiler house - is possible. Also within the concession agreement [4-7] 70\% of building areas should be allocated for cultural and creative activity, 30\% - for commercial activities. In order to draw conclusions about transformation of the object it is necessary to analyze the criteria for the quality of the urban space, its physical and social environment.

\footnotetext{
*Corresponding author: talililiva@gmail.com
} 


\section{Research of the physical and social environment}

Objects of the physical urban environment include buildings and structures, gardening, natural objects, objects of small architectural forms, transport, roads, advertising signs and banners [8-10]. Research borders were identified that amounted to a radius of $1 \mathrm{~km}$ (Figure 1). On the investigated site, gardening areas were identified, with the aim of analyzing the percentage ratio of gardening to the territory. This indicator was $5 \%$, which indicates the lack of gardening (Figure 2).

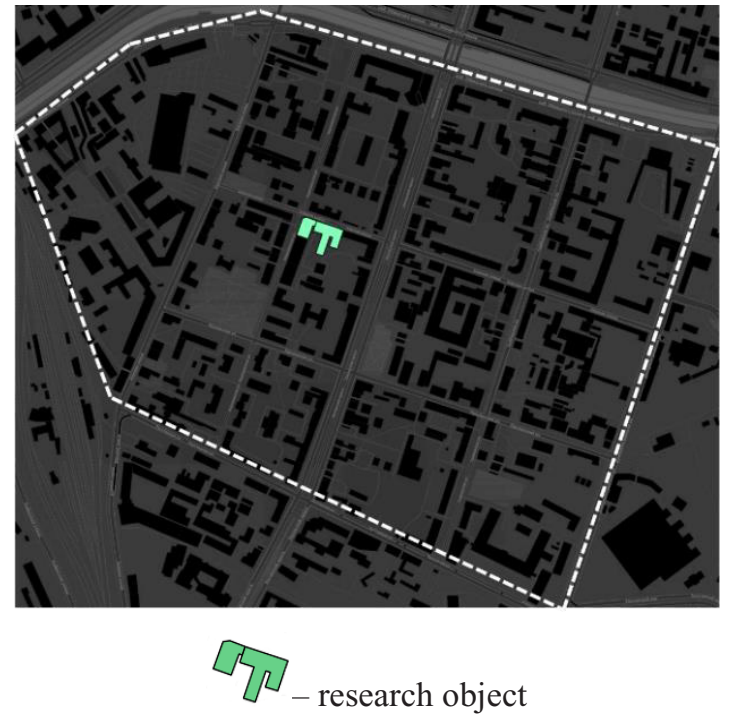

Fig. 1. Research borders.

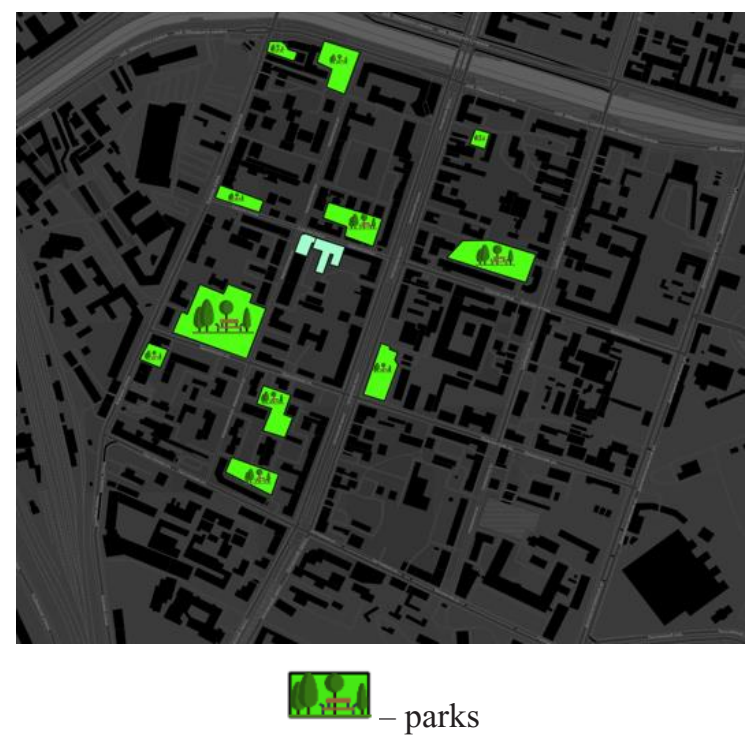

Fig. 2. Sites of gardening. 
Analyzing the transport accessibility to the object of the study (Figure 3), it can be noted that the site has a developed network of public transport. Moreover, the metro station is in 3 minutes of walking from the object. The city center can be reached by public transportat in 15 minutes.

Only the main highway Ligovsky Prospect (Figure 4) is susceptible to noise pollution, in the rest of the territory it is comfortable, due to lack of noise sources.

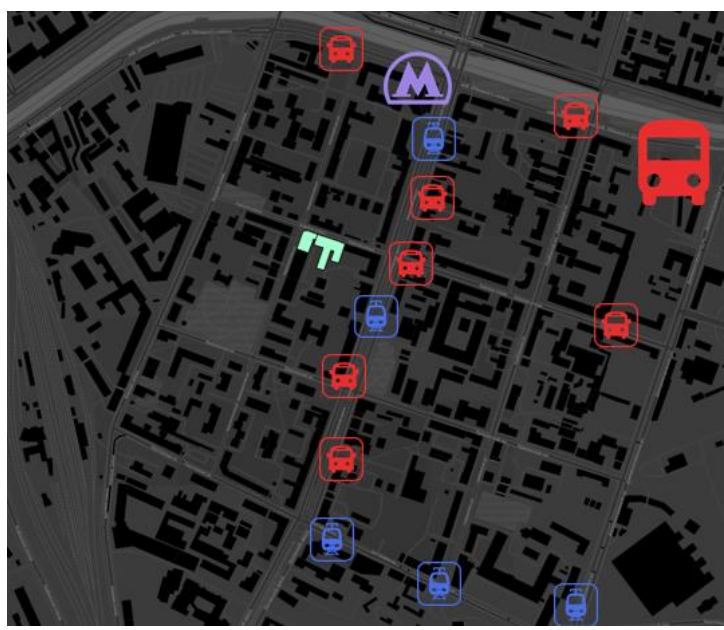

$$
\begin{aligned}
& \text { - metro station «Obvodnyi canal»; } \\
& \text { - bus station; } \\
& \text { - bus stops; } \\
& \text { - tram stops. }
\end{aligned}
$$

Fig. 3. Transport accessibility.
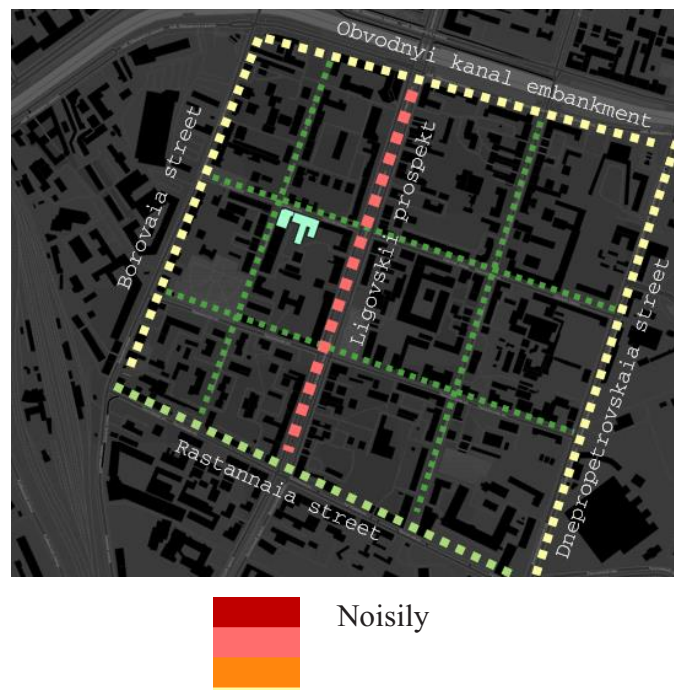

quietly

Fig. 4. Noise pollution map. 
An analysis of the activity of the research area was also made (Figure 5); residential (36\%) and non-residential (64\%) real estate objects were identified. Objects of social infrastructure were detailed (Figure 6), which include 4 buildings of universities, 2 schools, 2 kindergartens, 2 hospitals. High business activity was noted on the site, due to the presence of a large number of commercial activities, of which $37 \%$ are cafes and bars; $23 \%$ retail stores; $20 \%$ food stores; $10 \%$ of pharmacies and $10 \%$ of car centers. The quality of services provided in public trade enterprises is low, since most of them offer fast food and do not expect communication in a cozy environment.

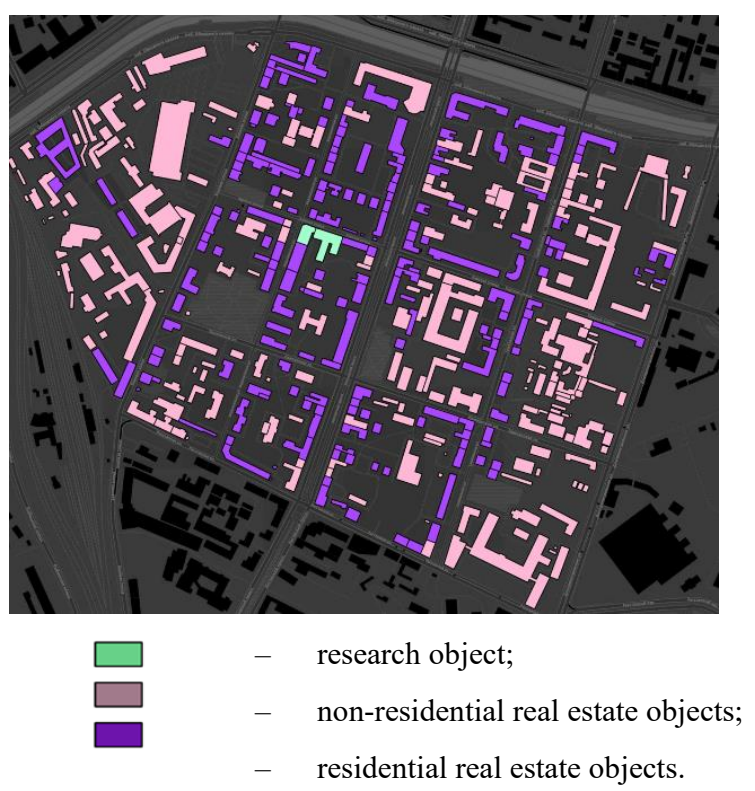

Fig. 5. The ratio of residential and non-residential real estate objects.

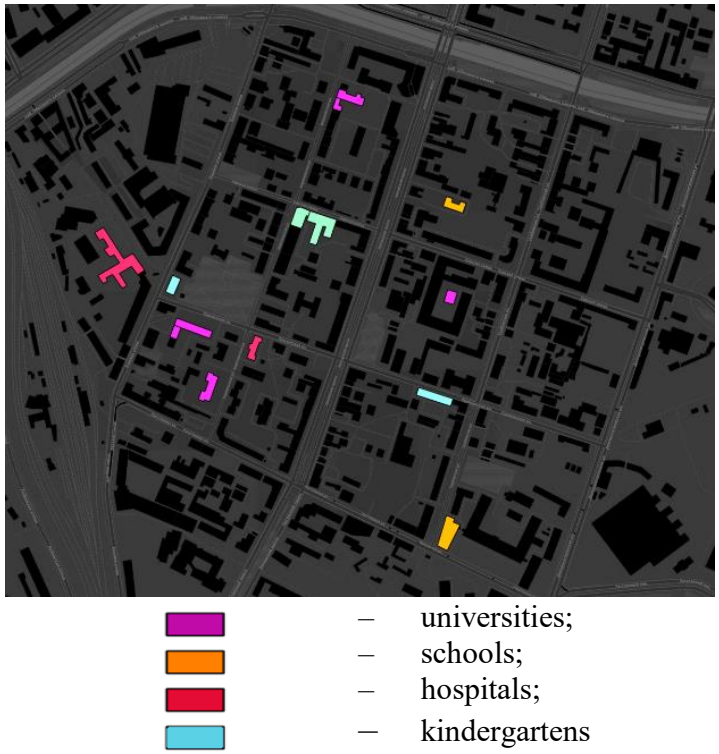

Fig. 6. Objects of social infrastructure. 
On the research territory there is an aggressive visual environment [11-15], expressed by dissimilar and gaudy advertising signs, non-functional open spaces, abandoned cars, pointed buildings of new residential buildings, abandoned buildings and an abundance of parking areas filled by $20 \%$.

Social scenarios for use of the territory are of two kinds: obligatory and optional. Obligatory social scenarios include work, service, transit, to optional - a meeting place, leisure. The more optional scenarios, the better the environment. In the analysis of the social environment, it was revealed that the territory is actively used by people of different ages. $20 \%$ of them are under 20 years old, $35 \%$ are $20-30$ years old, $25 \%$ are $30-55$ years old, $20 \%$ are older than 55 years old. Popular social scenarios for the research object are work, walking with children, smoking, rest on the children's playground and transit, due to the proximity of the metro station. The main social types identified during the analysis are students, office workers, pensioners, workers and mothers with children. At the moment, there are no optional social scenarios on the territory.

\section{Results}

According to the results of the research, it is expedient to reconstruct this object for co-living. The purpose of co-living is to create a home environment that inspires and empowers its residents to be active creators and participants in the world around them. These environments cultivate collaboration and serendipity amongst residents and the extended community. Coliving houses enable sustainable lifestyles through sharing and efficient use of resources and space.

Co-living is for people who want a home environment that actively supports them in living with purpose and intention. People who choose co-living include professionals, makers, entrepreneurs, artists, and creatives. Residents unite around a common interest to collaboratively manage a space, share resources, and coordinate activities, which contribute creatively and intellectually to the world around them. Many co-living houses offer shortterm accommodation and host outward facing events, increasing connections with the broader community and world.

The interior space of the building will be divided into 2 functional zones (Figure 7):

I. City functional zone for wide audience

II. Quarterly functional area:

1. Education:
a) arrangement of conference halls,
b) co-working,
c) laboratories,
d) residences of independent education;
2. Leisure:
a) coffee house,
b) baths,
c) gym,
d) yoga rooms,
e) board games club,
f) public spaces;
3. Lifestyle:
a) appartments,
b) laundry,
c) open kitchen. 


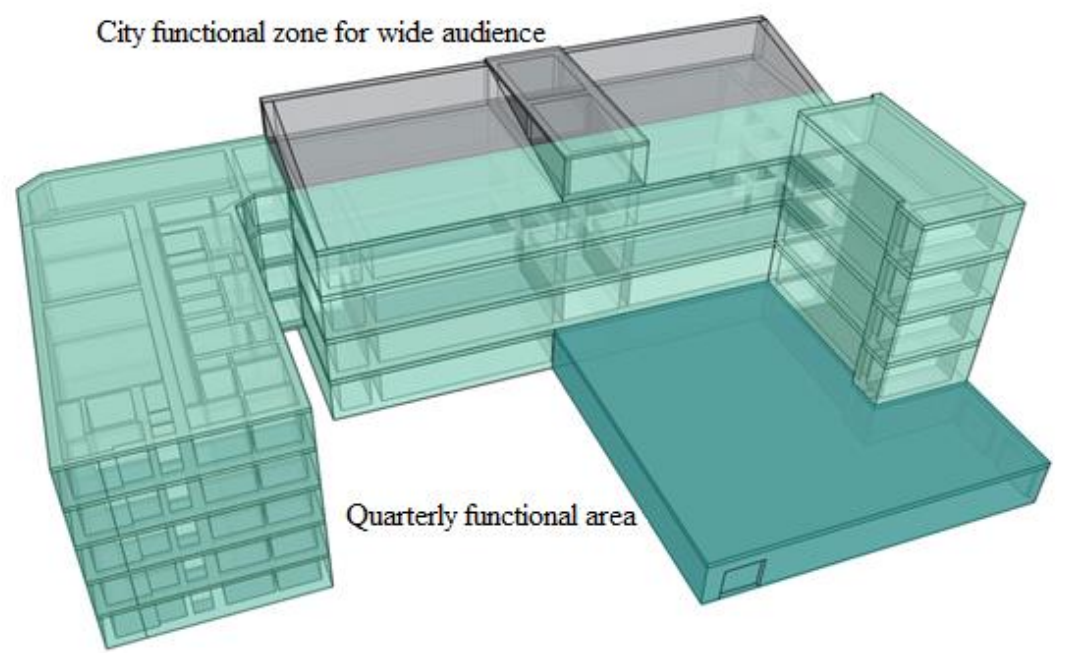

Fig. 7. Functional zones.

When carrying out the reconstruction on the territory of the object, it is planned to demolish the existing boiler house and construct a stylobate. The sequence of works is shown in Figure 8.
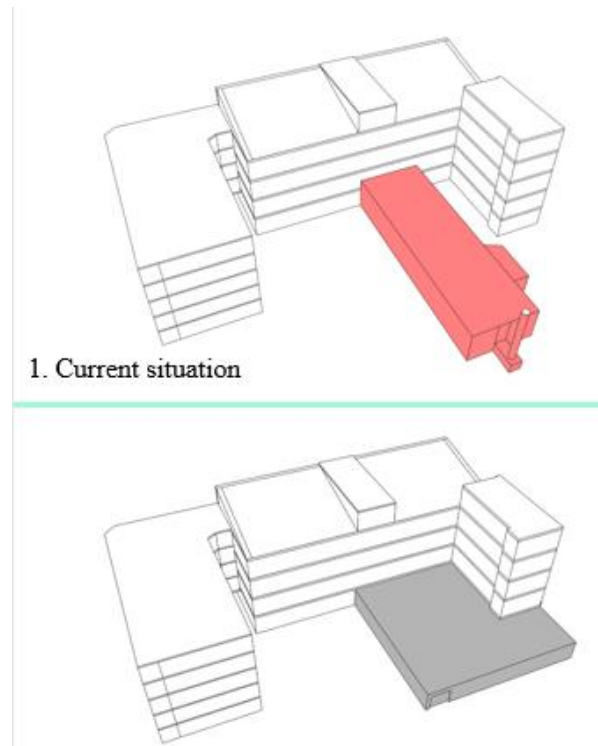

3. Stylobate construction with parking

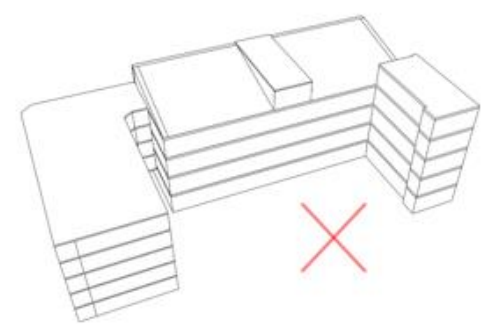

2. Boiler house demolition

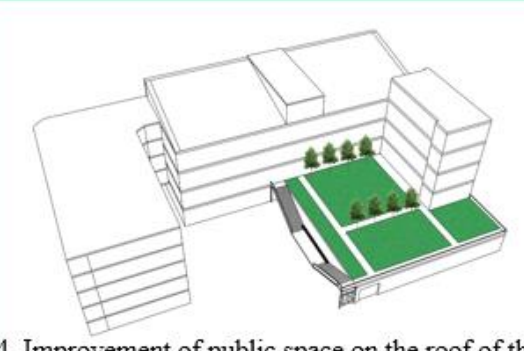

4. Improvement of public space on the roof of the parking lot

Fig. 8. Reconstruction stages.

The target audience of a co-living is people of 18-35 years old. They can use this place for working, temporary housing, new acquaintances and new experience.

\section{Discussion}

Co-living is a ratio of cultural and educational areas of $70 \%$ and commercial areas of $30 \%$. The main income from the operation of the object will come from renting rooms for 
commercial activities, delivery of apartments and attraction of commercial projects. Based on the results of the co-living creation, the object may have potential partners, which can be divided into 2 groups: developers, creative clusters. Cooperation with such partners as "Tchachi", "Etagi" will help create a strong cultural cluster.

Basic profitability of the areas makes a ratio of 30\% for high-profitable areas and $70 \%$ for the low-profitable areas. After application the business model (Figure 9), it is possible to increase the high-profitable areas to $65 \%$, which will accelerate the payback of this project. For creation of a co-living, initial investments of more than 300 million rubles are required; the payback period will be about 10 years.

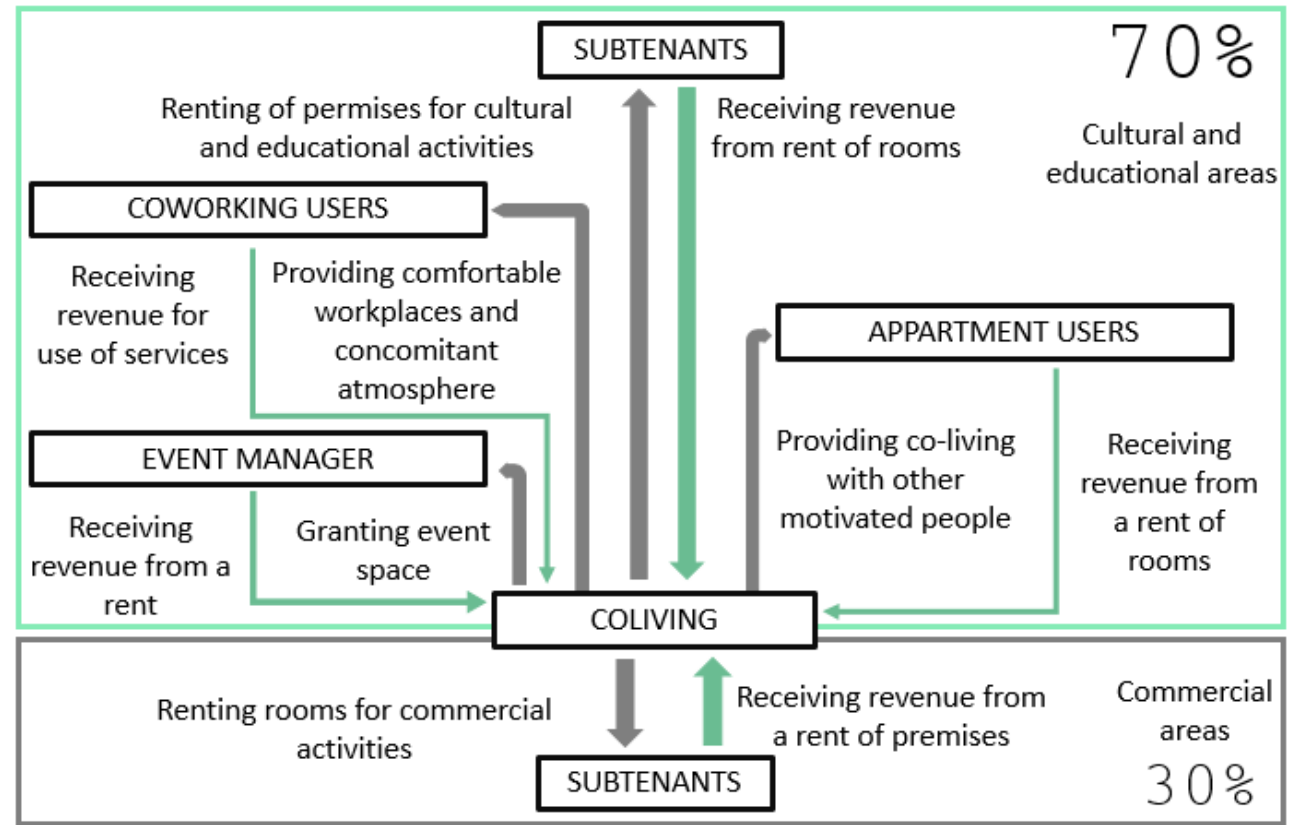

Fig. 9. Business model.

\section{Conclusions}

For a visual demonstration of the results of the physical and social environment study, a SWOT analysis was compiled in Table 1.

Table 1. SWOT analysis.

\begin{tabular}{|c|c|}
\hline Strengths & Weaknesses \\
\hline $\begin{array}{l}\text { - Location } \\
\text { - Lack of noise pollution } \\
\text { - Transport accessibility } \\
\text { - Developed social infrastructure }\end{array}$ & $\begin{array}{l}\text { - Expenses for reconstruction } \\
\text { - Insufficient gardening } \\
\text { - } \quad \text { Not well-groomed environment } \\
\text { Insufficient lighting }\end{array}$ \\
\hline Opportunities & Threats \\
\hline $\begin{array}{l}\text { - A large number of students } \\
\text { - A large number of employees } \\
\text { - Inflow of new residents } \\
\text { - Interest from developers } \\
\end{array}$ & $\begin{array}{ll}\text { - } & \text { Strong competitors } \\
\text { - } & \text { Social differentiation } \\
\text { - } & \text { Prerequisites for the development of } \\
& \text { criminality }\end{array}$ \\
\hline
\end{tabular}

Reconstruction of the object and change of its functional purpose for co-living will lead to an improvement in the visual environment, creation of public space, gardening of the 
surrounding area, the creation of a visual code, the creation of a new point of development and growth of the district. The residents of surrounding houses and nearby territories, students studying in neighboring universities, business centers, hotels can become interested parties which in a consequence will use functional spaces of a co-living.

According to urban sociologist Ray Oldenburg, people need three types of places to live fulfilled, connected lives: Their "first place" (home) for private respite; their "second place" (work) for economic engagement; and their "third place," a more amorphous arena used for reaffirming social bonds and community identities [16].

This third place can be a barbershop, neighborhood bar, community center, or even a public square. The desire for these three separate spheres drives how human environments are designed at a bedrock level, but increasing urbanism-as well as geographic and economic mobility - are collapsing these multiple spaces into one. The result is a new hybrid building type: co-living. Co-living is an opportunity for youth development, a place for uniting the residents of the district, partnership with universities, development of the district's business, and a catalyst for development of the whole district.

\section{References}

1. L. Talipova, E. Kosyakov, I. Polyakova, IOP Conference Series: Earth and Environmental Science, 012071 (2017)

2. "Grey belt. Transforming". Contest results. http://old.kgainfo.spb.ru/greybelt/main.html

3. K. Dyson, J. Matthews, P.E.D. Love, Built Environment Project Asset Management 61, 44-57 (2016)

4. The federal law from 7.21.2005 N 115-FZ (an edition from 12.312017) "About concession agreements"

5. F. Ascione, F. Ceroni, R.F. De Masi, F. de' Rossi, M.R. Pecce, Applied Energy 185, 1517-1528 (2017)

6. V.L. Castaldo., A.L. Pisello., P. Boarin, A. Petrozzi, F. Cotana, Buildings 2-2, 54 (2017)

7. M.C. Dejaco, F. Re Cecconi, S. Maltese, Journal of Building Engineering 9, 17-28 (2017)

8. G. Croatto, U. Turrin, A. Bertolazzi, Journal of Architectural Conservation 22-3, 189198 (2016)

9. K. Dyson, J. Matthews, P.E.D. Love, Built Environment Project Asset Management 61, 44-57 (2016)

10. P.A. Jensen, E. Maslesa, Building and Environment 92, 1-9 (2015)

11. J. Ferreira, M. Duarte Pinheiro, J. De Brito, Journal of Building Engineering 3, 114-126 (2015)

12. A. Thorpe, Offshore Engineer 40-1, 50-53 (2015)

13. F. Ascione, F. De Rossi, G.P. Vanoli, Energy and Buildings 43-8, 1925-1936 (2011)

14. S. Fernandez, Structural Engineer 89-3, 21-25 (2011)

15. V.L. Castaldo, A.L. Pisello, P. Boarin, A. Petrozzi, F. Cotana, Buildings 2-2, 54 (2017)

16. Live, Work, Play: WeLive's Live-Work Spaces Reveal a "Third Place". Redshift by Autodesk (2016) https://www.autodesk.com/redshift/live-work-spaces/ 